\title{
NOTES
}

\section{Notes to Introduction}

I Maurício Moura and Juliano Corbellini, A eleição disruptiva: por que Bolsonaro venceu (Editora Record, 2019), I5.

2 Cas Mudde and Cristóbal Rovira Kaltwasser, Populism: A Very Short Introduction (Oxford University Press, 2017), 5.

3 Ibid., 2 I.

4 Néstor Kirchner (2003-07) and his wife Cristina Fernández de Kirchner (2007-I5) led left-wing Peronist administrations in Argentina. Since 2019 Cristina Fernández has served as deputy president in another left-wing government led by former minister Alberto Fernández (2003-08). The current president shares the same name as his deputy, but the two are not related. Bolivia's Evo Morales held office between 2005 and 2019. In Ecuador, Rafael Correa and his left-wing PAISA party held office between 2006 and 2017. His former deputy, Lenin Moreno, won elections in 2017 but has followed a more moderate political course and has pursued a number of his former colleagues for corruption. Finally, Daniel Ortega, the former Sandinista guerrilla leader, has been president of Nicaragua since 2007. He was previously Nicaragua's president from I979 until I990. During this century more moderate left-wing governments have also held office in Chile, Uruguay, Peru, and briefly in Paraguay.

5 Roger Eatwell and Matthew Goodwin, National Populism: The Revolt Against Liberal Democracy (Pelican, 2018), 55.

6 See Francis Fukuyama, Identity: Contemporary Identity Politics and the Struggle for Recognition (Profile Books, 2018), Kindle edition, loc. I64I.

7 See David Runciman, How Democracy Ends (Profile Books, 2018), Kindle edition, loc. 834 .

8 Sheila S. Coronel, "The vigilante president: how Duterte's brutal populism conquered the Philippines", Foreign Affairs, September-October 
2018, https://www.foreignaffairs.com/articles/philippines/2019-08-I2/ vigilante-president (accessed 7 December 2020).

9 See Marc Plattner, "Illiberal democracy and the struggle on the right", Fournal of Democracy 30, no. I (2019): 5-19; Cas Mudde, "The 2019 elections: moving the center", fournal of Democracy 30, no. 4 (2019): 20-34.

Io See "Third of Brexit voters believe Muslim immigration is part of a secret plot to Islamicise Britain, study suggests", The Independent, 23 November 20I8, https://www.independent.co.uk/news/uk/home-news/brexit-vot ers-immigration-muslims-islam-leave-remain-yougov-survey-trump-a864 8586.html (accessed 6 January 202I).

I I See Fiona Macaulay, "Bancada da bala: the growing influence of the security sector in Brazilian politics", in Conor Foley (ed.), In Spite of You: Bolsonaro and the New Brazilian Resistance (OR Books, 2019), Kindle edition, loc. 983 .

I2 Renato Sérgio de Lima and Samira Bueno, "A tropa de choque de Bolsonaro", Piaui, 8 August 2020, https://piaui.folha.uol.com.br/tropade-choque-de-bolsonaro/ (accessed I5 February 202I).

\section{Notes to Chapter 1}

I As reported to Ingrid Fagundez, "Bolsonaro: a infância do presidente entre quilombolas, guerrilheiros e a rica família de Rubens Paiva", BBC News, I6 January 20I9, https://www.bbc.com/portuguese/brasil46845753 (accessed 7 December 2020).

2 Ibid.

3 "The life and rise and Captain Bolsonaro", El País, I January 20 I9, https: / / brasil.elpais.com/brasil/2018/Io/I9/politica/I539969259_I7I085.html (accessed 7 December 2020).

4 Fagundez, "Bolsonaro: a infância do presidente".

5 Luiz Maklouf Carvalho, O cadete e o capitão: a vida de Fair Bolsonaro no quartel (Todavia, 2019), 22.

6 Ibid., 36.

7 Ibid., 43 .

8 Thaís Oyama, Tormenta: o governo Bolsonaro: crises, intrigas e segredos (Companhia das Letras, 2020), 36 .

9 Ibid., 37.

Io Timothy J. Power, "The Brazilian military regime of I964-I985: legacies for contemporary democracy", Iberoamericana I6, no. 2 (2016): I3-26 (20), doi: I0.1844I/ibam.

I I See Jairo Nicolau, "The open list electoral system in Brazil", trans. Plínio Dentzien, Dados - Revista de Ciências Sociais 49, no. 4 (2006): 689-720.

I2 Power, "The Brazilian military regime of I964-I985", I7. 


\section{NOTES}

I3 See Scott Mainwaring, Rethinking Party Systems in the Case of Brazil (Stanford University Press, I999), quoted in Power, "The Brazilian military regime of I964-I985", 20.

I4 Oyama, Tormenta, II.

I5 Glenn Greenwald and Andrew Fishman, "The most misogynistic, hateful elected official in the democratic world: Brazil's Jair Bolsonaro", The Intercept, II December 2014, https://theintercept.com/20I4/I2/II/mis ogynistic-hateful-elected-official-democacratic-world-brazils-jair-bolson aro/ (accessed 8 December 2020).

I6 See "Who is Jair Bolsonaro? Brazil's far-right president in his own words", The Guardian, 29 October 2018, https://www.theguardian.com/ world/2018/sep/o6/jair-bolsonaro-brazil-tropical-trump-who-hankersfor-days-of-dictatorship (accessed 8 December 2020).

I7 Ibid.

I8 Jenny Gonzales, "Amazon threatened by presidential election. Brazil might follow Trump out of Paris Agreement”, 2I September 2018, https:// www.brazzil.com/amazon-threatened-by-presidential-election-brazil-mi ght-follow-trump-out-of-paris-agreement/ (accessed I5 February 202I); Mariana Simões, "Brazil's polarizing new president, Jair Bolsonaro, in his own words", New York Times, 28 October 2018, https://www.nytimes. $\mathrm{com} / 20 \mathrm{I} 8 / \mathrm{IO} / 28 /$ world/americas/brazil-president-jair-bolsonaro-quot es.html (accessed I5 February 202I).

I9 See Brian Winter, "Messiah complex: how Brazil made Bolsonaro", Foreign Affairs, September/October 2020, https://www.foreignaffairs. com/articles/brazil/2020-08-II/jair-bolsonaro-messiah-complex (accessed 6 January 202I).

20 See Alberto Carlos Almedia, A cabeça do Brasileiro (Editora Record, 2007).

2I See "Latinobarómetro: Opinión Pública Latinoamericana", https:// www.latinobarometro.org/lat.jsp (accessed 5 January 202I).

22 See the National Truth Commission, National Archives, Ministry of Justice and Public Security, http://www.memoriasreveladas.gov.br/ (accessed 8 December 2020).

23 Power, "The Brazilian military regime of I964-I985", I6.

24 Ibid., I5.

25 Ibid., I6.

\section{Notes to Chapter 2}

I Moura and Corbellini, $A$ eleição disruptiva, I45-6.

2 Jairo Nicolau, "O triunfo do Bolsonarismo", Piaui, November 2018, https://piaui.folha.uol.com.br/materia/o-triunfo-do-bolsonarismo/ (accessed 8 December 2020). 
3 Ibid. Marine Le Pen lost by 66. I per cent to 33.9 per cent to Emanuel Macron in the second round of France's 2017 presidential election.

4 Wendy Hunter and Timothy Power, "Bolsonaro and Brazil's illiberal backlash", fournal of Democracy 30, no. I (2019): 68-82 (69), doi: Io.I353/ jod.2019.0005.

5 Moura and Corbellini, A eleição disruptiva, 7I.

6 Ibid., 74 .

7 Pedro Henrique Alves, "Uma análise factual sobre Jair Bolsonaro", Instituto Liberal, 30 August 2018, https://www.institutoliberal.org.br/ blog/politica/uma-analise-factual-sobre-jair-bolsonaro/ (accessed 9 December 2020).

8 See Chris Tenove and Grace Chiang, "The meme-ification of politics: politicians \& their 'lit' memes", The Conversation, 4 February 2019, https:// theconversation.com/the-meme-ification-of-politics-politicians-and-theirlit-memes-i ioor7 (accessed 9 December 2020).

9 See Valdecir Becker, Daniel Gambaro and Guida Lemos Souza Filho, "The impact of digital media on Brazilian TV: ratings drop and higher turnover", Palgrave Clave I8, no. 2 (2015): 34I-73, doi: 10.5294/ pacla.20I5.18.2.3.

IO Moura and Corbellini, A eleição disruptiva, I I5.

I I Ibid., iı-66.

I2 See annual surveys of Latin Barometer, https://www.latinobarometro. org/lat.jsp (accessed 6 January 202I).

I3 Moura and Corbellini, A eleição disruptiva, I2 I.

I4 Terrence McCoy, "He's the Rush Limbaugh of Brazil. He has Bolsonaro's ear. And he lives in rural Virginia", The Washington Post, I4 July 20I9, https://www.washingtonpost.com/world/the_americas/hesthe-rush-limbaugh-of-brazil-he-has-bolsonaros-ear-and-he-lives-in-ruralvirginia/2019/o7/I4/4f73dee2-8ac4-I Ieg-8f69-a2795fca3343_story.html (accessed 9 December 2020).

I5 Letícia Duarte, "Meet the intellectual founder of Brazil's far right", The Atlantic, 28 September 2019, https://www.theatlantic.com/inter national/archive/20 I9/ I2/brazil-olavo-de-carvalho-jair-bolsonaro/6o 4II / (accessed 9 December 2020).

I6 Moura and Corbellini, A eleição disruptiva, I22.

I7 Brian Winter, "Jair Bolsonaro's guru", Americas Quarterly, i7 December 20I8, https://www.americasquarterly.org/article/jair-bolsonaros-guru/ (accessed 9 December 2020).

I8 As reported in McCoy, "He's the Rush Limbaugh of Brazil".

I9 As reported in Duarte, "Meet the intellectual founder of Brazil's far right". Video available at https://www.facebook.com/jairmessias.bol sonaro/videos/945681038957259/ (accessed 6 January 2020). 
20 Consuelo Dieguez, "Right flank, march", Piaui, September 20i6, https://piaui.folha.uol.com.br/materia/right-flank-march/ (accessed 9 December 2020).

2I Aryovaldo de Castro Azevedo Junior and Eriza Cristina Verderio Biano, "O processo de mitificação de Bolsonaro: Messias, presidente do Brasil", Revista Pos Eco 22, no. 2 (2019): 88-I I I, doi: Io.29I46/eco-pos.v22i2.26253.

22 Moura and Corbellini, A eleição disruptiva, I26.

23 Josette Goulart and Marcella Ramos, "Bolsonaro transfere seu sucesso na internet para a TV", Piauí, 31 July 20I8, https://piaui.folha.uol.com. br/bolsonaro-transfere-seu-sucesso-na-internet-para-a-tv/ (accessed 9 December 2020).

24 Miguel Lago, "Bolsonaro fala outra língua", Piauí, I3 August 2018, https://piaui.folha.uol.com.br/bolsonaro-fala-outra-lingua/ (accessed 9 December 2020).

25 Moura and Corbellini, A eleição disruptiva, I26.

26 Ibid., I27.

\section{Notes to Chapter 3}

I Jonathan Wheatley, "A bright new future is just out of reach", Financial Times, 6 May 20Io, https://www.ft.com/content/adeo7aca-57Ic-IIdfaaff-oo 44 feab49a (accessed 9 December 2020).

2 Rating agencies - privately owned companies mostly based in the US, although the dominant two, Moody's and Standard \& Poor's, have faced competition from Europe and elsewhere in recent years - charge borrowers or bond issuers to rate their creditworthiness. Some of the biggest players on world capital markets, such as large pension funds or large life insurance companies, are restricted from buying riskier debt (classified as speculative grade or junk in the industry), so Brazil's promotion - and its subsequent relegation back to junk less than a decade later - were important steps.

3 "Acima das expectativas, Lula encerra mandato com melhor avaliação da história", Datafolha Instituto de Pesquisas, 20 December 20Io, http:// datafolha.folha.uol.com.br/opiniaopublica/2010/I2/ I2 I I078-acima-dasexpectativas-lula-encerra-mandato-com-melhor-avaliacao-da-historia. shtml (accessed 26 December 2020.

4 See "Brazil takes off", The Economist, I2 November 2009, https:// www.economist.com/leaders/2009/II/I2/brazil-takes-off (accessed 9 December 2020).

5 Claudia Safatle, João Borges and Ribamar Oliveira, Anatomia de um desastre: os bastidores da crisis econômica que mergulhou o país na pior recessão de sua historia (Portfolio Penguin, 2016), I65. 
6 Most of his investment schemes proved to have been badly planned. In 2018 Batista was found guilty on corruption charges and jailed for thirty years.

7 Safatle, Borges and Oliveira, Anatomia de um desastre, 220.

8 See João Ayres, Marcio Garcia, Diogo Guillen and Patrick Kehoe, The Monetary and Fiscal History of Brazil, I960-20I6 (University College London/Federal Reserve Bank of Minneapolis, December 2018). "One of the most striking features of Brazilian monetary and fiscal history is its long period of high inflation pre-I994 ... Inflation rates were closely related to the growth rates of the monetary base and to seigniorage revenues."

9 The cruzeiro was replaced as Brazil's currency by the cruzado in February I986 and the cruzado by the cruzado novo in January I989. After my wife left Brazil, the cruzado novo was replaced by another version of the cruzeiro, and finally in i994, the cruzeiro was replaced by the real.

Io See Michael Reid, Brazil: The Troubled Rise of a Global Power (Yale University Press, 2014), I42.

I I Ibid., I42.

I2 Ibid., 40-I47.

I3 Jorge Blázquez-Lidoy, Javier Rodríguez and Javier Santiso, "Angel or Devil? Chinese trade impact on emerging markets", OECD Working Paper no. 252 (2004), https://www.oecd.org/dev/37054336.pdf (accessed Io December 2020).

I4 See Safatle, Borges and Oliveira, Anatomia de um desastre, 222.

I5 Reid, Brazil, I99-204.

I6 Author interview with Vanessa Mara, 2007.

I7 See Richard Lapper and Raymond Colitt, "Brazil comes of age on the global stage", Financial Times, I4 September 2004, https://www.ft.com/ content/68gdbdf2-o68I-I Idy-b95e-0ooooe25I Ic8 (accessed i4 December 2020).

I8 Cumulatively between 2004 and 2007, the trade surplus amounted to \$ 65 billion.

I9 See Richard Lapper and Jonathan Wheatley, "Interview transcript: Luiz Inácio Lula da Silva", Financial Times, I I July 2006, https://www.ft.com/ content/6d42ae3a-I Iob-IIdb-9a72-0ooo779e2340 (accessed 6 January 2020).

20 Reid, Brazil, I46-7.

2I Author interview with Helenita Santana, September 2006.

22 Back in 2003 I'd interviewed Ivo Pitanguy, a larger-than-life plastic surgeon who compared his role to that of a psychotherapist and was known as 'the Michelangelo of the Scalpel' and the 'Pope of Plastic Surgery'. "Many times when we are operating we are like therapists with a knife in 
our hand", he told me. Pitanguy, who was 93 when he died in 20r6, was a superstar, best known for his association with people like Jacqueline Onassis and Frank Sinatra, but his prominence as a surgeon reflected a broader Brazilian obsession.

23 See "Classe C impulsionou venda de passagens aéreas entre 2002 e 2012", Instituto Tecnologico de Aeronautica, Nucleo de Economia dos Transportes Aéreo, http:/ / www.ita.br/noticias53 (accessed I4 December 2020).

24 Lula introduced a grant scheme (Prouni) that channelled help to hundreds of thousands of students. Subsequently, in 20I0, the government introduced a loan scheme through which it offered to pay further education fees upfront and allow students to repay after they graduated, with the loans carrying negative real interest rates. The Prouni scheme was extended to technical education in $201 \mathrm{I}$.

\section{Notes to Chapter 4}

I For details of Rousseff's experiences in the guerrilla movement and prison, see Luiz Maklouf Carvalho, "As armas e os varões: a educação política e sentimental de Dilma Rousseff”, Piauí, April 2009, https:// piaui.folha.uol.com.br/materia/as-armas-e-os-varoes/ (accessed I4 December 2020).

2 Luiz Maklouf Carvalho, "Mares nunca dantes navegados: a trajetória de Dilma Rousseff da prisão ao poder - e como ela se tornou a candidata do presidente Lula à sua sucessão", Piauí, July 2009, https://piaui.folha.uol. com.br/materia/mares-nunca-dantes-navegados/ (accessed I4 December 2020).

3 Ibid.

4 The term was first used in December 2012 by the then secretary of political economy, Márcio Holland, in a ministry publication. Holland said the matrix was characterised by "low interest rates, low financial costs, a more competitive exchange rate and a solid fiscal result". His advisers had been cautious about branding their approach as new because - in the words of one minister - "all [our enemies] need is a label to hit us with". Safatle, Borges and Oliveira, Anatomia de um desastre, 93.

5 The Brazilian economy advanced by 2 per cent in 2012 and 3 per cent in 2014 .

6 Safatle, Borges, and Oliveira, Anatomia de um desastre, IO2.

7 See Carvalho, "Mares nunca dantes navegados".

8 Quoted in Safatle, Borges and Oliveira, Anatomia de um desastre, 26o.

9 Only $\$ 0.13$ of every $\$ 1$ of bad debt is recovered in Brazil, compared to a world average of $\$ 0.34$, according to a World Bank survey. This is 
mainly because of complications in the legal system and legal protections afforded to borrowers. Banks include a provision against bad loans in their loans equal to 40 per cent of the spread.

IO In 2016 Brazil spent $\mathrm{R} \$ 498.5$ bn on state pensions for 29 million privatesector pensioners (providing an average payout of $\mathrm{R} \$ \mathrm{I} 7,080$ a year), but $\mathrm{R}$ \$IIobn on just I million public-sector pensioners (who received average annual pensions of $\mathrm{R} \$$ II $\left._{3}, 060\right)$. See Jonathan Wheatley and Andrés Schipani, "'Robin Hood in reverse': the crisis in the Brazilian state", Financial Times, I3 September 2018, https://www.ft.com/content/7555do3o-gfebi ie8-85da-eeb7agce36e 4 (accessed i4 December 2020).

I I Ibid.

I2 Marcos de Barros Lisboa and Zeina Abdel Latif, Democracy and Growth in Brazil, Insper working paper (2013), https://www.insper.edu.br/wpcontent/uploads/2013/07/Democracy_and_Growth_in_Brazil.pdf (accessed 14 December 2020).

I3 See Fernando Henrique Cardoso and Enzo Faletto, Dependency and Development in Latin America, trans. Marjory Mattingly Urquidi (University of California Press, 1979).

I4 Cardoso and Faletti wrote about the possibility of what they called "associated dependent development". See Gaylord George Candler, "Cardoso, dependency theory and Brazil", paper presented to the International Studies Association, Midwest, St Louis, ig October 1996.

I5 See Fernando Henrique Cardoso, O presidente segundo o sociólogo: entrevista FHC with Roberto Pompeu de Toledo (Companhia das Letras, 1998).

I6 Safatle, Borges and Oliveira, Anatomia de um desastre, I9-29.

I7 Ibid., 257.

I8 Ibid., 233 .

I9 Ibid., I55.

20 Ibid., 229-45. Although junior to Mantega and other ministers, Augustín was nonetheless a powerful figure who enjoyed direct access to the president.

2I Twenty-to-thirty-year airport concessions assumed annual growth rates of 4.5 per cent per year, for example, a rate of expansion that would have made the airport in Brasília one of the biggest in the world.

22 Leandra Peres, "O aviso foi dado: pedaladas faz mal", Valor Econômico, I I December 2015, https://www.bocamaldita.com/o-aviso-foi-dado-peda lar-faz-mal/ (accessed I4 December 2020).

23 Ibid.

24 Safatle, Borges and Oliveira, Anatomia de um desastre, II3.

25 Ibid., I26.

26 Ibid., I9I-202.

27 Ibid., I42. 
28 Ibid., $163-78$.

29 Ibid., I70.

\section{Notes to Chapter 5}

I See "Growing number of Brazilians optimistic about the economy, says Datafolha", Invest in Brazil, http://investinbrazil.biz/news/growingnumber-brazilians-optimistic-about-economy-says-datafolha (accessed 6 January 202I).

2 Brian Winter, "Revisiting Brazil's 2013 protests: what did they really mean?", Americas Quarterly, I March 2017, https://www.americasquarterly. org/article/revisiting-brazils-2013-protests-what-did-they-really-mean/ (accessed I5 December 2020).

3 André Singer, O Lulismo em crise: um quebra cabeça do período Dilma, 20II-20I6 (Companhia das Letras, 2018), 28.

4 See "Editorial: retomar a Paulista", Folha de São Paulo, i3 June 2013, https://wwwi.folha.uol.com.br/opiniao/2013/o6/i294185-editorial-ret omar-a-paulista.shtml (accessed 6 January 202I).

5 Ibid.

6 See H.J. "The streets erupt", The Economist, r8 June 2013, https://www. economist.com/americas-view/2013/o6/18/the-streets-erupt (accessed I5 December 2020).

7 Winter, "Revisiting Brazil's 2013 protests".

8 Ibid.

9 Singer, O Lulismo em crise, I25.

Io See Luiz Eduardo Soares, Rio de faneiro: Extreme City (Penguin, 20 I6), 2 Iо.

II Ibid.

I2 See Singer, O Lulismo em crise, i Io.

I3 More than half of the Brazilians interviewed in Latin Barómetro's 2013 survey of political attitudes were using one or other form of social media, with Facebook by far the most popular. The proportion had climbed to nearly three-quarters when the polling agency conducted its 2018 survey.

I4 Claudia Miranda Rodrigues, "Narrativas jornalísticas e midiativismo: um estudo de caso sobre as rotinas produtivas do coletivo Mídia Ninja", Masters thesis, the Pontificial Universidade Católica de Rio de Janeiro, 2016.

I5 See Soares, Rio de Faneiro, 227.

I6 Francisco Peregil, "Biggest protests in 20 years sweep across Brazil", El País, I8 June 2013, https://english.elpais.com/elpais/2013/o6/18/ineng lish/I371568124_920323.html (accessed I5 December 2020).

I7 Ronald Inglehart and Christian Welzel, Modernização, mudança cultural e democracia (Francis, 2009), I30, quoted in Singer, O Lulismo em crise, I22. 
I8 Singer, O Lulismo em crise, 122-3.

I9 See Soares, Rio de Faneiro, 2 Iо.

20 Thomas Traumann, "What Brazil's 2013 protests tell us about Chile 2019", Americas Quarterly, 27 October 2019, https://www.americasqu arterly.org/article/what-brazils-20 I3-protests-tell-us-about-chile-20I9/ (accessed I5 December 2020).

2I Vladimir Netto, The Mechanism (Penguin, 2017), 8I.

22 Ibid., 370.

23 Geanluca Lorenzon, "Corruption and the rule of law: how Brazil strengthened its legal system", Cato Institute 827 (20 November 2017), https://www. cato.org/publications/policy-analysis/corruption-rule-law-how-brazil-str engthened-its-legal-system (accessed I5 December 2020).

24 See Netto, The Mechanism, 37.

25 See Ernesto Londońo, "Judges bid to clean up Brazil from the bench", New Tork Times, 25 August 2017, https://www.nytimes.com/2017/08/25/ world/americas/judge-sergio-moro-brazil-anti-corruption.html (accessed I5 December 2020).

26 Joe Leahy, "Sérgio Moro: the judge cleaning up Brazil", Financial Times, i7 May 2018, https://www.ft.com/video/2834eebb-9ebc-4677-a3be-bc6 3a39f7ice (accessed 6 January 202I).

27 Netto, The Mechanism, 8I.

28 Ibid., 64 .

\section{Notes to Chapter 6}

I The Trial was written between I9I4 and I9I5 and published after Kafka's death in I924. The scene was brilliantly captured in Petra Costa's 2015 documentary film The Edge of Democracy.

2 Singer, O Lulismo em crise, I89.

3 Netto, The Mechanism, 503.

4 Tancredo died from diverticulitis before taking office. Neves had been elected indirectly by an electoral college.

5 Malu Gaspar, "A morte e a morte de Joaquim Levy", Piauí, December 2015, https://piaui.folha.uol.com.br/materia/morte-e-morte-de-joaqu im-levy/ (accessed I5 December 2020).

6 Singer, O Lutismo em crise, 197.

7 Ibid., I99.

8 Rodrigo Janot, Planeta nada menos que tudo: bastidores da operação que colocou o sistema politico em xeque (Planeta, 2019), I27.

9 The investigating judge is theoretically at least independent from the team of prosecutors, although both the structure of the Brazilian system 
and the specific relationships between Judge Motro and the prosecution team in Curitíba have been widely questioned by critics.

Io Netto, The Mechanism, 266.

I I See ibid., 227-31.

I2 Author interview with Brazilian journalist, July 2020.

I3 Singer, O Lulismo em crise, 242.

I4 See Janot, Planeta nada menos que tudo, I29.

I5 See Fabio de Sá e Silva, "The trial of Luiz Inácio Lula da Silva", in Conor Foley (ed.), In Spite of You: Bolsonaro and the New Brazilian Resistance (OR Books, 2019), 32-46.

I6 Ibid., 37 .

I7 See Andrew Fishman, Rafael Moro Martins, Leandro Demori, Alexandre de Danti and Glenn Greenwald, "Breath of ethics: secret Brazil archive", The Intercept, 9 June 2019, https://theintercept.com/2019/o6/og/bra zil-lula-operation-car-wash-sergio-moro/ (accessed I5 December 2020).

I8 Eight years earlier, the MDB had won I2.54 million votes in the legislative election and 24 million votes in the senate race. In the same year even though it had been comprehensively defeated in the presidential contest - the PSDB attracted I I.48 million votes in the legislative contest and 30.9 million votes in the race for senate seats. In 2018 both parties lost between a half and a third of their voters, with the MDB down to 5.44 million in the house and 12.8 million in the senate, and the PSDB at 5.9I million in the house and 20.3 million in the senate.

I9 "The demise of Brazil's great centrist party", The Economist, 3 November 2018, https://www.economist.com/the-americas/2018/II/o3/the-dem ise-of-brazils-great-centrist-party (accessed I5 December 2020).

20 See Janot, Planeta nada menos que tudo, 43.

\section{Notes to Chapter 7}

I Richard Lapper, "Against the tide: why it is so hard to stop the violence in Brazil", Americas Quarterly, I8 July 2018, https://www.americasquar terly.org/fulltextarticle/against-the-tide-why-its-so-hard-to-stop-the-vio lence-in-brazil/ (accessed I5 February 202I).

2 https://www.youtube.com/watch? $=J N_{c} V o C y r 8 b U \& t=62 \mathrm{~s}$ (accessed I5 February 202I).

3 The PT's Camilo Santana was re-elected for a second term as state governor in 2018. Santana has recruited thousands of policemen and prison guards and spent heavily on weaponry and equipment. Since December 2018 the state government has also led a big change in prison policy, forcing prisoners from different gangs to share cells, removing televisions and electrical fittings from cells, and confiscating mobile phones. See Richard 
Lapper, "This Brazilian state seems to have turned a corner on violence. But can it last?", Americas Quarterly, 6 August, 2019, https://www.ameri casquarterly.org/article/this-brazilian-state-seems-to-have-turned-a-cor ner-on-violence-but-can-it-last/ (accessed I5 February 202I).

4 Author interview with Daniel Cerqueira, i I July 2019.

5 Brian Winter, "What to expect from Jair Bolsonaro", Americas Quarterly, 9 October 2018, https://www.americasquarterly.org/article/what-toexpect-from-jair-bolsonaro/ (accessed I5 December 2020).

6 See "Human Rights Watch World Report I998", Human Rights Watch, 3 December I997, https://www.hrw.org/news/I997/I2/o3/humanrights-watch-world-report-I998 (accessed I5 December 2020); Marcelo Rocha and Silva Zorovich, "Beyond overcrowding: the decline of the Brazilian penitentiary system", in Jonathan D. Rosen and Marten W. Brienen (eds), Prisons in the Americas in the Twenty-First Century: A Human Dumping Ground (Lexington Books, 2016), I83-94.

7 Drauzio Varella, Estação Carandiru (Companhia das Letras, I999).

8 Bruno Paes Manso and Camila Nunes Dias, A guerra: a ascensão do PCC e o mundo do crime no Brasil (Todavia, 2018), Kindle edition, loc. II48.

9 Quoted in Paes Manso and Dias, A guerra, loc. 3315.

Io César Muñoz, "Prison conditions worsen in Brazil", Human Rights Watch, 8 December 2017, https://www.hrw.org/news/2017/I2/o8/prison-con ditions-worsen-brazil (accessed 7 January 202I).

I I According to one estimate, by the end of 2012, 6,400 of the 8,000 members of the PCG in São Paulo - a staggering 80 per cent of the total were in the prison system. See Paes Manso and Dias, A guerra.

I2 Ibid., loc. II77.

I3 See ibid.

I4 Author interview with Luiz Fabio Silva Paiva, 9 May 2018.

I5 Gabriel Feltran, The Entangled City: Crime as Urban Fabric in São Paulo (Manchester University Press, 2020), I42.

I6 See Stephanie Nolen, "How Brazil's big experiment in policing failed to make Rio safer for the Olympics", The Globe and Mail, 2 August 2016, https://www.theglobeandmail.com/news/world/how-brazils-big-polici ng-experiment-failed-to-make-rio-safer-for-theolympics/article31222945/ (accessed 15 December 2020).

I7 See Misha Glenny, Nemesis: One Man and the Battle for Rio (Bodley Head, 20I5).

I8 Feltran, The Entangled City, I43.

I9 See Allan de Abreu, Cocaína: a rota caipira (Editora Record, 2017).

20 Beira-Mar was Luiz Fernando da Costa, and his nickname was derived from the Rio favela that he controlled on behalf of the Red Command.

2I See Paes Manso and Dias, A guerra. 
22 See Gabriel Stargardter, "Brazil's gangs emerge as major cocaine exporters, flooding Europe with white powder", Reuters, I2 March 2020, https:/ / uk.reuters.com/article/uk-brazil-violence-cocaine-specialreport-idUKK BN20ZiCU (accessed 7 January 202I).

23 See Fabio Serapião, "Fornecedor de droga da Família do Norte é ligado às Farc, diz MPF", O Estado de São Paulo, 4 January 2017, https://brasil. estadao.com.br/noticias/geral,fornecedor-de-droga-da-familia-do-nortee-ligado-as-farc-diz-mpf, Iooooog8I57 (accessed 7 January 202I).

24 See Chris Feliciano Arnold, The Third Bank of the River: Power and Survival in the Twenty-First Century Amazon (Picador, 2018), I39.

25 Aline Ribeiro, "A íntegra do 'salve' que explica as guerras entre facções”, Época, I9 October 2016, https://epoca.globo.com/tempo/ noticia/2016/ı/integra-do-salve-que-explica-guerras-entre-faccoes.html (accessed I5 December 2020).

26 Ibid.

\section{Notes to Chapter 8}

I Allan de Abreu, "A metástase", Piauí, March 2019, https://piaui.folha. uol.com.br/materia/a-metastase/ (accessed 6 January 202I).

2 Fernando de Barros e Silva, "Pastores, polícias e milícias", Piaui, 29 October 2020, https://piaui.folha.uol.com.br/pastores-policias-e-mili cias/ (accessed 6 January 202I).

3 Author interview with Simone Sibilio, 27 November 2020; "Rio de Janeiro's militias: a parallel power in Bolsonaro's Brazil", Financial Times, 25 March 20I9, https://www.ft.com/content/bdd6i7i8-4bio-I Ieg-bbc9 -6917dce3dc62 (accessed 6 January 202I).

4 Anthony Pereira, "Paper cemeteries, informal barriers to Brazilian public security reform", Revista da Ciência Policial Brasileira Io, no. I (2019): 55-98.

5 Ibid., 6o.

6 Mercedes Hinton, The State on the Streets: Police and Politics in Argentina and Brazil (Lynne Rienner Publishers, 2006), Iо I.

7 Clara Velasco, Felipe Grandin, Gabriela Caesar and Thiago Reis, " $\mathrm{N}^{\mathrm{o}}$ de pessoas mortas pela polícia cresce no Brasil no $\mathrm{I}^{\mathrm{o}}$ semestre em plena pandemia; assassinatos de policiais também sobem", GI Monitor da Violência, 3 September 2020, https://gi.globo.com/monitor-da-violencia/ noticia/2020/og/o3/no-de-pessoas-mortas-pela-policia-cresce-no-brasilno-Io-semestre-em-plena-pandemia-assassinatos-de-policiais-tambem-so bem.ghtml (accessed 6 January 202I).

8 Dom Philips, "Police in Brazilian city aided revenge killings, report says", Washington Post, 7 March 20 I5, https://www.washingtonpost.com/world/ the_americas/after-cop-turned-gangster-is-shot-revenge-killings-rip-bra 
zilian-city-apart/2015/o3/o6/9d6e7a3e-ci I I-I Ie4-ar88-8e497Id37a8d_s tory.html (accessed 6 January 202I); Final Report of the Parliamentary Commission of Inquiry into the operation of extermination groups and militias in the State of Pará, Legislative Assembly of Pará State (Relatório Final, Comissão Parlamentar de Inquérito para Apuração da Atuação de Grupos de Extermínio e Milícias no Estado do Pará, Assembleia Legislativa do Estado do Pará), 3o January 2015. https://alpara.com.br/ midias/midias/I I_relatorio_final_da_comissao_parlamentar_de_inque rito_para_apuracao_da_atuacao_de_grupos_de_exterminio_e_milicias_ no_estado_do_para-teste-envio.pdf (accessed 7 January 202I).

9 Author interview with Bruno Paes Manso, December 2020.

Io The population of Rio de Janeiro's centre and established suburbs declined between 1970 and 1990, but overall - including these newly settled areas to the north and west - the population increased from 4.3 million to 5.8 million.

I I See Bruno Paes Manso, A república das milícias: dos esquadrões de morte à era do Bolsonaro (Todavia, 2020), Kindle edition, loc. 136.

I2 Ibid., loc. I68.

I3 Ibid., loc. 249 .

I4 Dom Philips, "Lesser evil': how Brazil's militias wield terror to seize power from gangs", The Guardian, I8 July 2018, https://www.theguardian. $\mathrm{com} /$ world/2018/jul/ı2/brazil-militia-paramilitary-wield-terror-seize-po wer-from-drug-gangs (accessed 6 January 202I).

I5 See Paes Manso, A república das milícias, loc. 957.

I6 Ibid.

I7 Ibid., loc. 312.

I8 In Brazil, firemen or bombeiros militares constitute a police unit subject to the orders of elected state governors.

I9 Marcos Sá Corrêa, "Agora é tolerância total: Cesar Maia diz por que prefere as milícias aos traficantes”, Piaui, March 2007, https://piaui. folha.uol.com.br/materia/agora-e-tolerancia-total/ (accessed 6 January 202I).

20 Malu Gaspar, "O pitbull de papai”, Piauí, July 20r9, https://piaui.folha. uol.com.br/materia/o-pit-bull-do-papai/ (accessed 6 January 202I).

2 I Luigi Mazzo, "Os condenados e os condecorados", Piauí, 22 February 2019, https://piaui.folha.uol.com.br/flavio-os-condenados-e-os-condec orados/ (accessed 6 January 202I).

22 Ibid.

23 See Paes Manso, A república das milícias, loc. 729.

24 Ibid., loc. 742 .

25 Ibid., loc. $782-9$.

26 Italo Nogueira and Cristina Camargo, "Flávio Bolsonaro é denunciado sob acusação de liderar organisazação criminosa da 'rachadinha", Folha de São 
Paulo, 4 November 2020, https://wwwi.folha.uol.com.br/poder/2020/ I / ministerio-publico-denuncia-flavio-bolsonaro-por-organizacao-criminosapeculato-lavagem-de-dinheiro-e-apropriacao-indebita.shtml (accessed 6 January 202I).

27 Robert Muggah et al., "Rio de Janeiro's militia on the rise (again)", Open Democracy, 22 May 20I8, https://www.opendemocracy.net/en/democra ciaabierta/rio-de-janeiros-militia-on-rise-ag/ (accessed 6 January 202I).

28 José Nêumanne, "O poder político das milícias do Rio", O Estado de São Paulo, I9 October 2020, https://politica.estadao.com.br/blogs/neuman ne/o-poder-politico-das-milicias-do-rio/ (accessed 6 January 202I).

29 Author interview Bruno Paes Manso, ig November 2020.

30 Author interview with Simone Sibilio, 25 November 2020.

3 I Abreu, "A metástase".

32 See Centro de Estudos de Segurança e Cidadanía, https://cesecseguranca. com.br/participacao/pesquisa-datafolha-forum-brasileiro-de-segurancapublica-medo-de-milicia-supera-medo-de-traficante-nas-comunidades-ena-zona-sul-do-rio/ (accessed 6 January 202I).

33 Author interview with Simone Sibilio, 25 November 2020.

34 Ibid.

35 The ministry of justice and public security is the parent agency of three smaller forces, the highways, national and federal police.

36 See Pereira, "Paper cemeteries", 60.

37 Ibid; Júlia Leite Valente, "Polícia militar é um oximoro, a militarização da segurança pública no Brasil", Revista do Laboratório de Estudos da Violência da UNESP, December 2012, https://revistas.marilia.unesp.br/index. $\mathrm{php} /$ levs/article/view/2646 (accessed 6 January 202I).

$3^{8}$ Renata Mendonça, "Está na hora de mudar a estrutura da polícia brasileira?", BBC News Brasil, i I February 2017, https://www.bbc.com/por tuguese/brasil-38895293, (accessed 6 January 202I).

39 See Macaulay, "Bancada da bala", loc. 982.

40 In a formal sense the lower house of the Brazilian congress brings together groups of deputies concerned with security matters in two bodies: the Parliamentary Front for Public Security, which in 2018 had 247 deputies, and the Permanent Commission of Public Security, which had 66. These groups provide a forum for politicians who have a range of views and who do necessarily agree that repression is the best tactic. Nor do members of these committees necessarily have military or police backgrounds. A more narrowly defined caucus would include those deputies who have a police or military background. In a recent study, Eveline Ribeiro dos Santos of the University of Brasília defines this as the "hard-core" bullet bench. See Eveline Ribeiro dos Santos, "A bancada da bala na cámara, quem são e que propõem esses deputados", MA thesis, Universidade Federal de Brasília, 2018. And to add a further twist, for the first time in 
2018 seven army officers were elected to parliament, all for Bolsonaro's PSL. These officers have proposed forming a separate bancada militar. Although the Brazilian armed forces are often brought into domestic policing issues - and at least one general, Girão Monteiro, had been involved in running a state police force - they see themselves as separate from, and superior to, the military police and would prefer that the term 'militar' was used exclusively for the armed forces.

4I Ribeiro dos Santos, "A bancada da bala na cámara"; author interview with Eveline Santos, June 2020.

42 Renato Sérgio de Lima and Samira Bueno, "A tropa de choque de Bolsonaro", Piaui, 8 August 2020, https://piaui.folha.uol.com.br/tropade-choque-de-bolsonaro/ (accessed 6 January 202I).

\section{Notes to Chapter 9}

I In Brazilian Portuguese, the term evangélico refers to all Protestants. The term evangelist - someone who spreads the gospel - could refer to either Catholics or Protestants, although in Brazil this category of Catholics is more generally referred to as 'charismatic'. I'm indebted to Amy Erika Smith for the distinction.

2 Datafolha predicted that among Catholics, Bolsonaro would win 29.94 million votes against 28.77 million for Haddad. Among evangelicals he would win 21.7 million votes against 9.75 million for the PT's candidate. See José Eustáquio Diniz Alves, "O voto evangélico garantiu a eleição de Jair Bolsonaro", EcoDebate, 3I October 2018, https://www.ecodebate.com. br/2018/Io/3I/o-voto-evangelico-garantiu-a-eleicao-de-jair-bolsonaro-ar tigo-de-jose-eustaquio-diniz-alves/ (accessed i5 December 2020).

3 Ibid.

4 The sheer number of churches in Brazil is also impressive, having risen from 97,239 in 2003 to I80,4I in 2014 and to an estimated 220,000 in 2020 (that compares with only I6,000 in the UK and 300,000 in US). See figures from "Imunidade de igrejas é usada para lavagem de dinheiro", Consultor Furídico, 25 March 20I4, https://www.conjur.com.br/20I4-mar-25/imuni dade-tributaria-igrejas-utilizada-lavagem-dinheiro (accessed i5 December 2020).

5 Lamia Oualalou, "Los evangélicos y el hermano Bolsonaro", Nueva Sociedad 28o (March-April 20I9), https://nuso.org/articulo/los-evangeli cos-y-el-hermano-bolsonaro/ (accessed 7 January 202I).

6 The founder, Manoel de Mello e Silva, left his native Pernambuco to work on construction sites in São Paulo, and after seeing a vision of Christ he began to preach, and rapidly recruited followers in the working-class suburbs of eastern São Paulo. 
7 The philosophy developed in the nineteenth century by Allan Kardec, a French teacher and philosopher, is the best known spiritist doctrine in Brazil, even though it was formally prohibited by the Catholic hierarchy in 1917 .

8 Author interview with Paul Freston, I8 March 2020.

9 See Edir Macedo and Nada A. Perder, Mina história (Unipro Editora, 2018); Gilberto Nascimento, O Reino: a história de Edir Macedo e um radiografia da Igreja Universal (Companhia das Letras, 2020).

Io Robert McAlister, a Canadian missionary whose broadcast sermons had initially excited Macedo's interest, was one of the first to bring the new message to Brazil. But two US theologians, Essek Williams Kenyon and Kenneth Hagin, had been pioneers of these ideas. They offered biblical justification for controversially arguing that financial and material wellbeing were the will of God, and that by contrast physical suffering, poverty and disease reflected an absence of faith. See Kate Bowler, Blessed: A History of the American Prosperity Gospel (Oxford University Press, 2013).

I I Edir Macedo and Margarida Oliva, O diabo no reino de Deus, I39, quoted in Odêmio Antonio Ferrari, Bispo S/A: A Igreja Universal do Reino de Deus e o exercício do poder (Editora Ave-Maria, 2012), Kindle edition, loc. I56r.

I2 Ricardo Mariano, O reino da prosperidade da Igreja Universal, 253, quoted in Ferrari, Bispo $S / A$, loc. 2060.

I3 Paul Freston, A Igreja Universal do Reino de Deus, Nem anjos nem demônios, I45, quoted in Ferrari, Bispo $S / A$, loc. 2568.

I4 See Nascimento, $O$ Reino, esp. chs 4 and 5, for a comprehensive recent history.

I5 Author interview with Ramos, July 2019.

I6 Ari Pedro Oro and Marcelo Tadvald, "Consideraciones sobre el campo evangêlico brasileño", Nueva Sociedad 28o (March-April 20I9), https:// nuso.org/media/articles/downloads/3.TG_Oro_28o.pdf (accessed 7 January 202I).

I7 Thanks to Michael Stott, Latin America editor at the Financial Times, for this detail. In a report written in December 2019, Stott describes the São Paulo church as a "Brazilian version [of the temple] with creature comforts King Solomon would not have recognised: air conditioning, cinemastyle seating in padded chairs, giant screens, a sound system worthy of a rock concert and a giant underground car park." See Michael Stott, "Brazil's evangelical church preaches the Bolsonaro revolution", Financial Times, i6 December 20i9, https://www.ft.com/content/e7a47ig6-i8I7I Iea-gee4-IIf2604I5385 (accessed 7 January 202I).

I8 Alex Cuadros, Brazillionaires (Profile Books, 20i6), iıo.

I9 Stott, "Brazil's evangelical church preaches the Bolsonaro revolution".

20 Brand Arenari, "Pentecostalism as religion of periphery: an analysis of Brazilian case", $\mathrm{PhD}$ thesis, Humboldt Universität zu Berlin, 2013. 
2I Author interview with Paul Freston, I8 March 2020.

22 Cesar Romero Jacob, Dora Rodrigues Hees, Philippe Waniez and Violette Brustlein, "Eleições presidenciais de 2002 no Brasil: uma nova geografia eleitoral?”, $A L C E U_{3}$, no. 6 (2003): 287-327.

23 See Paul Freston, "Pentecostalism and global politics: three questionable approaches", Institute of Culture, Religion and World Affairs, 3 March 2014 .

24 Ibid.

25 Ibid.

26 Author interview with Paul Freston, I8 March 2020.

27 Author interview with Amy Erika Smith, 27 December 2020.

28 Amy Erika Smith, Religion and Brazilian Democracy: Mobilising the People of God (Cambridge University Press, 2019).

29 Javier Corrales, "Understanding the uneven spread of LGBT rights in Latin America and the Caribbean, 1999-2013", Fournal of Research in Gender Studies 7, no. 52 (2017): 52-82, doi: I0.2238I/JRGS7I20172.

30 Maria das Dores Campos Machado, "Aborto e ativismo nas eleiçoes de 2010", Revista Brasileira de Ciência Política 7 (2012), http://dx.doi. org/Io.I590/Soro3-33522012000100003 (accessed 7 January 202I).

$3^{\text {I }}$ Ibid.

32 Nascimento, O Reino, 290-I.

33 Fernando Haddad, "Viví na pele o que aprendi nos livros", Piauí, June 20I7, https://piaui.folha.uol.com.br/materia/vivi-na-pele-o-queaprendi-nos-livros/ (accessed 7 January 2020).

34 Marcella Ramos, "Pedofilia, estupro, incesto, dois boatos de difamação desmentidos por dia no segundo turno", Piauí, 28 October 2018, https:// piaui.folha.uol.com.br/pedofilia-estupro-incesto-dois-boatos-de-difamac ao-desmentidos-por-dia-no-20-turno/ (accessed I5 February 2020).

35 Author interview, 3 July 2019.

$3^{6}$ Gay marriage was effectively legalised by a Supreme Court decision of 2013 , although the right remains fragile.

\section{Notes to Chapter 10}

I Author interview with Ramalho, 5 February 2020.

2 Author interview with Viera, January 2020.

3 See O Estado de São Paulo, I2 April 2018.

4 Susanna B. Hecht and Alexander Cockburn, The Fate of the Forest (University of Chicago Press, 2010), I22.

5 John Hemming, Tree of Rivers: The Story of the Amazon (Thames and Hudson, 2012), Kindle Edition, loc. I365. 


\section{NOTES}

6 Quoted in Adriana Gomes Santos, "Garimpos e trababalhadores dos garimpos: o intricado jogo de interesses políticos e econômicos em Roraima", MA thesis, Universidad Federal de Uberlândia, 5, https:// www.historia.uff.br/estadoepoder/7snep/docs/o88.pdf (accessed 20 November 2020).

7 David Cleary, Anatomy of the Amazon Gold Rush (University of Iowa Press, I990), I7I.

8 Gordon MacMillan, At the End of the Rainbow? Gold, Land and People in the Brazilian Amazon (Columbia University Press, I995), 37.

9 "Haunting black and white images of the Brazilian gold rush by Sebastião Salgado", The Independent, ig September 2019, https://www.independ ent.co.uk/arts-entertainment/photography/haunting-black-white-pho tos-brazil-gold-sebastiao-salgado-agiıoo3r.html (accessed I5 December 2020).

Io See Heloisa M. Starling and Lilia Moritz Schwarcz, Brazil: A Biography (Allen Lane, 20I8), esp. ch. 4.

i See also Getúlio de Souza Cruz, Ambientalismo e indigenismo: Roraima com laboratório dos regimes internacionais (Editora Leitura XXI, 2016).

I2 Augusto Heleno, speech to Club Militar Rio de Janeiro, April 2008, quoted in Eugênia Lopes, Luciana Nunes Leal and Tânia Monteiro, "Lula cobra general por crítica à reserve Raposa Serra do Sol", O Estado de São Paulo, I7 April 2008.

\section{Notes to Chapter 11}

I See Kris Bramwell, "Brazil fires prompt 'prayers' for Amazon rainforest", BBC News, 23 August 2019, https://www.bbc.co.uk/news/blogstrending-494065I9 (accessed I5 December 2020).

2 See Phoebe Weston, "Amazon rainforest fires: Jair Bolsonaro sends Brazilian army to put out huge blaze as G7 leaders hold emergency talks", The Independent, 24 August 2019, https://www.independent.co.uk/ environment/amazon-rainforest-fires-latest-brazil-army-jair-bolsonarog7-a9077I7.html (accessed i5 December 2020).

3 See Jonathan Watts, "Jair Bolsonaro claims NGOs behind Amazon forest fire surge - but provides no evidence", The Guardian, 2I August 2019, https://www.theguardian.com/world/20ig/aug/2i/jair-bolson aro-accuses-ngos-setting-fire-amazon-rainforest (accessed I5 December 2020).

4 Thomas Lovejoy and Carlos Nobre, "Amazon tipping point: last chance for action", Science Advances 5, no. I2 (20 December 2019), https:// advances.sciencemag.org/content/5/I2/eaba2949 (accessed 7 January 202I). 
5 See https://rainforests.mongabay.com/amazon/deforestation-rate.html for updated monthly numbers.

6 See "Under Brazil's far-right leader, Amazon protections slashed and forests fall", New York Times, 28 July 2019, https://www.nytimes. $\mathrm{com} / 2019 / \mathrm{o} 7 / 28 /$ world/americas/brazil-deforestation-amazon-bolson aro.html (accessed 7 January 202I).

7 Bernardo Esteves, "A guerra contra o termômetro", Piauí, September 20I9, https://piaui.folha.uol.com.br/materia/a-guerra-contra-o-termom etro/ (accessed 7 January 202I).

8 Fabiano Maisonnave and Lalo de Almeida, "A segunda morte de Chico Mendes", Folha de São Paulo, 6 March 2020, https://temas.folha.uol.com. $\mathrm{br} /$ amazonia-sob-bolsonaro/a-segunda-morte-de-chico-mendes/sob-bo lsonaro-ex-seringueiros-aceleram-desmatamento-e-a-troca-de-extrativis mo-por-gado.shtml (accessed 7January 202I).

9 Sergio Mergulis, Causes of Deforestation of the Brazilian Amazon, World Bank working paper no. 22 (World Bank, 2003), 9.

Io See Hemming, Tree of Rivers, loc. 5974.

I I Author interview with Roberto Mangabeira Unger, 23 July 2019.

I2 Ricardo Abramovay, Amazonia (Outras Palavras, 2019), 20.

I3 For a good account of the controversies surrounding Belo Monte, see Eliane Brum, Brasil, construtor de ruinas: um olhar sobre o Brasil, de Lula a Bolsonaro (Archipélago Editorial, 2019).

I4 See Bernardo Esteves, "O meio ambiente como estorvo", Piauí, June 20I9, https://piaui.folha.uol.com.br/materia/the-environment-as-anobstacle/ (accessed i5 December 2020).

I5 Ibid.

I6 Jon Lee Anderson, "Blood gold in the Brazilian rain forest", The New Yorker, 4 November 20I9, https://www.newyorker.com/magazine/ 20I9/II/I I/blood-gold-in-the-brazilian-rain-forest (accessed 7 January 202I).

I7 See Daniel Camargos, "Fazendeiros e empresários organizaram 'dia do fogo', apontam investigações", Folha de São Paulo, 23 October 20I9, https://wwwi.folha.uol.com.br/ambiente/2019/io/fazendeirose-empresarios-organizaram-dia-do-fogo-apontam-investigacoes.shtml (accessed 7 January 202I); Leandro Machado, "O que se sabe sobre o 'Dia do Fogo', momento-chave das queimadas na Amazônia”, BBC Brasil, I9 August 2019, https://www.bbc.com/portuguese/brasil-4945 3037 (accessed 7January 202I).

I8 See Daniel Camargos and Dom Phillips, “" "Dia do Fogo” foi invenção da imprensa', diz principal investigado por queimadas na Amazônia", Repórter Brasil, 25 October 2019, https://reporterbrasil.org.br/2019/ı/ dia-do-fogo-foi-invencao-da-imprensa-diz-principal-investigado-por-que imadas-na-amazonia/ (accessed 7 January 202I). 


\section{NOTES}

I9 https://www.nytimes.com/2019/ı/o6/video/amazon-rainforest-firesburning.html? searchResultPosition= $=_{\mathrm{I}}$ (accessed I $_{5}$ February 202 I).

20 Esteves, "O meio ambiente como estorvo".

2 I Ibid.

22 Ibid.

23 Ibid.

24 See Suely Araújo and Fabio Feldman, "Política ambiental, o que o orçamento mostra e promote", Valor Econômico, I5 January 2020, https:// valor.globo.com/opiniao/coluna/politica-ambiental-o-que-o-orcamen to-mostra-e-promete.ghtml (accessed 7 January 2020).

25 See Danielle Brant and Phillippe Watanabe, "Sob Bolsonaro, multas ambientais came 34\% para menor nível em 24 anos", Folha de São Paulo, 9 March 2020, https://wwwi.folha.uol.com.br/ambiente/2020/o3/sob-bolsonaromultas-ambientais-caem-34-para-menor-nivel-em-24-anos.shtml (accessed 7 January 202I).

26 Esteves, "O meio ambiente como estorvo".

27 Ibid.

28 Dom Phillips, "Bolsonaro pick for Funai agency horrifies indigenous leaders", The Guardian, 2I July 20I9, https://www.theguardian.com/ world/2019/jul/2 I/bolsonaro-funai-indigenous-agency-xavier-da-silva (accessed 7 January 202I).

29 Author interview with Luis Ventura, Boa Vista, 28 January 2020.

30 See Ernesto Londoño and Letícia Casado, "As Bolsonaro keeps Amazon vows, Brazil's indigenous fear 'ethnocide"", New York Times, I9 April 2020, https://www.nytimes.com/2020/o4/ig/world/americas/bolson aro-brazil-amazon-indigenous.html (accessed 7 January 202I).

3I Lovejoy and Nobre, "Amazon tipping point".

32 See Philip Stouffer, "Enigmatic bird declines in pristine Amazon rainforest", American Ornithological Society, I I November 2020, https://ame ricanornithology.org/enigmatic-bird-declines-in-pristine-amazon-rain forest/ (accessed 7 January 202I).

33 Author interview with Adriane Esquivel Muelbert, May 2020.

34 Lovejoy and Nobre, "Amazon tipping point".

\section{Notes to Chapter 12}

I See Richard Lapper, "Bolsonaro took aim at China. Then reality struck", Americas Quarterly, 23 April 2019, https://www.americasquarterly. org/article/bolsonaro-took-aim-at-china-then-reality-struck/ (accessed 7 January 202I).

2 See Daniel Yergin, The New Map: Energy, Climate, and the Clash of Nations (Penguin Press, 2020). 
3 For trade figures, see http://www.mdic.gov.br/index.php/comercioexterior/estatisticas-de-comercio-exterior/balanca-comercial-brasileiraacumulado-do-ano (accessed 7 January 202I), and https://www.statista. com/statistics/ I I05976/brazil-trade-value-china/ (accessed 7 January 202I).

4 See Su-Lin Tan, "Brazil mining giant Vale agrees deal with China port to expand iron ore handling capacity", South China Morning Post, I3 October 2020, https://www.scmp.com/economy/global-economy/ article/3105248/brazil-mining-giant-vale-agrees-deal-china-port-operator (accessed 7 January 202I).

5 See PWC survey at https://www.poder36o.com.br/infograficos/os-inv estimentos-da-china-no-brasil-e-o-quanto-isso-andou-em-2org/ (accessed 7January 202I).

6 Yergin, The New Map, I80-I.

7 Bruno Maçaes, Belt and Road: A Chinese World Order (Hurst, 2018).

8 Brenno Grillo, "Why is China investing in Brazilian oil, when no one else is?", Brazil Reports, I9 November 2019, https://brazilian.report/ business/2019/I I/ I9/china-investing-brazilian-oil-no-one-cnooc-cnodc/ (accessed 7 January 202I).

9 See Maçaes, Belt and Road, 79-8o.

Io Interview with author, July 2019.

I I Author interview with Rubens Sawaya, January 2019.

I2 Lapper, "Bolsonaro took aim at China".

I3 Ibid.

I4 "Brasil-China: por uma parceria estratégica global sustentável para o século XXI", http://www.cebri.org/portal/publicacoes/cebri-artigos/ position-papers-2018 (accessed I5 February 202I).

I5 Lapper, "Bolsonaro took aim at China".

\section{Notes to Chapter 13}

I See Celso Rocha de Barros, "How Lava Jato died - and what comes next", Americas Quarterly, I5 October 2019, https://www.americasquar terly.org/article/how-lava-jato-died-and-what-comes-next/ (accessed 6 January 202I).

2 Robert Simon, "Bolsonaro's siege against law enforcement agencies", Americas Quarterly, I2 September 2019, https://www.americasquarterly. org/article/bolsonaros-siege-against-law-enforcement-agencies/ (accessed 6 January 202I). See also André Shalders, "Bolsonaro cria 'situação dramática' ao tentar proteger Flávio, diz ex-procurador da Lava Jato", $B B C$ Brasil, I9 September 20I9, https://www.bbc.com/portuguese/brasil49562267 (accessed 6 January 202I). 
3 "Federal police names Carlos Bolsonaro as organizer of fake news criminal scheme", Folha de São Paulo, 25 April, 2020, https://wwwi.folha.uol. com.br/internacional/en/brazil/2020/o4/federal-police-names-carlosbolsonaro-as-organizer-of-fake-news-criminal-scheme.shtml (accessed 6 January 202I).

4 Patricia Campos de Mello, "Operação contra fake news reforça suspeitas das eleições de 2018", Folha de São Paulo, I June 2020, https://wwwi. folha.uol.com.br/poder/2020/o6/operacao-contra-fake-news-reforcasuspeitas-das-eleicoes-de-2018.shtml (accessed 6 January 202I).

5 Patricia Campos de Mello, "Brazil's troll army moves into the streets", New York Times, 4 August 2020, https://www.nytimes.com/2020/08/04/ opinion/bolsonaro-office-of-hate-brazil.html (accessed 6 January 202I).

6 Tom Philips, "Brazil's star justice minister Sergio Moro resigns in blow to Jair Bolsonaro", The Guardian, 24 April 2020, https://www.theguard ian.com/world/2020/apr/24/brazil-justice-minister-sergio-moro-resignsjair-bolsonaro (accessed 6 January 202I).

7 Vera Rosa, "Uma reunião ministerial com destempero verbal, ofensas e pitos", O Estado de São Paulo, 23 May 2020, https://politica.estadao.com. $\mathrm{br} /$ noticias/geral,uma-reuniao-ministerial-com-destempero-verbal-ofen sas-e-pitos,70003312050 (accessed 6 January 202I).

8 Ernesto Londoño, Letícia Casado and Manuela Andreoni, "AA perfect storm' in Brazil as troubles multiply for Bolsonaro", New York Times, 25 April 2020, https://www.nytimes.com/2020/04/25/world/americas/ bolsonaro-moro-brazil.html (accessed 6 January 202I).

9 Martim Vasques da Cunha, "Tragédia ideológica: o bolsolavismo foi o hospedeiro perfeito para as tendências totalitárias de uma geração", Piauí, August 2020, https://piaui.folha.uol.com.br/materia/tragediaideologica/ (accessed 6 January 202I).

Io Ernesto Araújo, "Trump e o ocidente", Cadernos de Política Exterior 3, no. 6 (2017): 345-6. English translation, https://www.centerforsecuritypolicy. org/about-us/ (accessed 24 December 2020).

I I Tom Hennigan, "Mystical influence agitating Brazil's Bolsonaro admin istration", Irish Times, 30 April 20I9, https://www.irishtimes.com/ news/world/mystical-influence-agitating-brazil-s-bolsonaro-administra tion-I.3875385 (accessed 6 January 202I).

I2 "Please don't let me be misunderstood: Jair Bolsonaro's contentious first year in office", The Economist, 4 January 2020, https://www.economist. $\mathrm{com} /$ the-americas/2020/oi/o4/jair-bolsonaros-contentious-first-year-inoffice (accessed 6 January 202I).

I3 General Walter Souza Braga Netto took over from Lorenzoni in 20I9, and General Eduardo Pazuello became the third health minister in 2020 . 
I4 Laís Lis, "Governo Bolsonaro mais que dobra número de militares em cargos civis, aponta TCU", GI, I7 July 2020, https://gi.globo.com/ politica/noticia/2020/o7/I7/governo-bolsonaro-tem-6157-militares-emcargos-civis-diz-tcu.ghtml (accessed I5 February 202I).

I5 Winter, "Messiah complex".

I6 Oliver Stuenkel, "The backlash against Brazil's politicised military", Americas Quarterly, 24 August 2020, https:/ /www.americasquarterly.org/ article/the-backlash-against-brazils-politicized-military/ (accessed 6 January 202I).

I7 Brian Winter, “It's complicated': inside Bolsonaro's relationship with Brazil's military", Americas Quarterly, I2 December 2019, https://www. americasquarterly.org/article/its-complicated-inside-bolsonaros-relation ship-with-brazils-military/ (accessed 6 January 202I).

I8 Fabio Victor, "O vice a cavalo: Hamilton Mourão e o lugar dos militares no governo Bolsonaro", Piauí, December 2018, https://piaui.folha.uol. com.br/materia/o-vice-cavalo/ (accessed 6 January 202I).

I9 Oyama, Tormenta, $3^{8 .}$

20 Victor, "O vice a cavalo".

2 I Ibid.

22 Oyama, Tormenta, 20-I.

23 Ibid., I48-9.

24 Hélio Schwartsman, "O presidente das pequenas coisas", Folha de São Paulo, 30 April 2019, quoted in Oyama, Tormenta, I39.

25 Oyama, Tormenta, I5 1 .

26 Jenny Gonzales, "Brazil minister advises using COVID-I9 to distract from Amazon deregulation", Mongabay, 26 May 2020, https://news. mongabay.com/2020/05/brazil-minister-advises-using-covid-r9-to-distr act-from-amazon-deregulation/ (accessed 6 January 202I).

27 Oyama, Tormenta, 93 .

28 Winter, "Messiah complex".

29 Ibid. The pension reform saved Brazil about $\mathrm{R} \$ 8$ oobn over a ten-year period.

30 Winter, "Messiah complex".

3I See Luiz Henrique Mandetta, Um paciente chamado Brasil (Objetiva, 2020).

32 Ibid., I43.

33 Monica Gugliano, "O dia em que Bolsonaro decidiu mandar tropas para o Supremo", Piaui, August 2020, https://piaui.folha.uol.com.br/ materia/vou-intervir/ (accessed 6 January 202I).

34 Brian Harris and Andrés Schipani, "Bolsonaro and the generals: will the military defend Brazil's democracy?", Financial Times, II August 2020, https://www.ft.com/content/86f36rao-c78c-4683-8dai-b5e337c98365 (accessed 6January 202I). 
35 Simon Romero, Letícia Casado and Manuela Andreoni, "Threat of military action rattles Brazil as virus deaths surge", New York Times, Io June 2020, https://www.nytimes.com/2020/o6/Io/world/americas/bo lsonaro-coup-coronavirus-brazil.html (accessed 6 January 202I).

\section{Notes to Chapter 14}

I Edoardo Ghirotto, José Benedito Da Silva and João Pedroso de Campos, "Auxílio emergencial: o risco da bonança artificial", Veja, 9 September 2020, https://veja.abril.com.br/economia/auxilio-emergencial-o-riscoda-bonanca-artificial/ (accessed I6 January 202I).

2 The payment rose to $\mathrm{R} \$ \mathrm{I}, 200$ for women with children, but fell to a flat $\mathrm{R} \$ 300$ in the last two months of the year. The payment was made automatically to beneficiaries of the Bolsa Familia and the so-called Cadastro Unico scheme.

3 During 2020 several separate teams of researchers pored over the impact of the emergency grant. For example, a study by researchers at the Pernambuco Federal University looked at the impact on different states and municipalities: Ecio de Farias Costa and Marcelo Acioly dos Santos Freire, "Estudo de avaliação do programa de auxílio emergencial: um análise sobre focalização e eficácia a nível municipal”, https://forum.outerspace. com.br/index.php?threads/estudo-de-avalia $\% \mathrm{C}_{3} \% 87 \% \mathrm{C}_{3} \% 830$-do-pro grama-de-aux $\% \mathrm{C}_{3} \% 8$ Dlio-emergencial-uma-an $\% \mathrm{C}_{3} \% 8$ Ilise-sobre-foca liza $\% \mathrm{C}_{3} \% 87 \% \mathrm{C}_{3} \% 83$ o-e-efic $\% \mathrm{C}_{3} \% 8$ icia-a-n $\% \mathrm{C}_{3} \% 8$ Dvel-municipal.56 270 / / (accessed I5 February 202I). Research by the Centre of Microfinance and Financial Inclusion of the FGV looked at the impact on different categories of workers: Lauro Gonzalez and Bruno Barreira, "Efeitos do auxílio emergencial sobre a renda", FGV EASP Centro de Estudos de Microfinanças e Inclusão Financiera, https://eaesp.fgv.br/producaointelectual/efeitos-auxilio-emergencial-sobre-renda (accessed I5 February 202I). Finally, Marcelo Neri of the Centre of Social Policy at the FGV led an investigation of the broader effect of the COVID-I9 pandemic on different economic classes, https://cps.fgv.br/pesquisas/covid-classeseconomicas-e-o-caminho-do-meio (accessed I5 February 202I).

4 Thomas Traumann, "Paulo Guedes' biggest dilemma", Americas Quarterly, I9 November 2020, https://www.americasquarterly.org/article/pauloguedes-biggest-dilemma/ (accessed i6 January 202I).

5 Datafolha, 8-ı December 2020, http://media.folha.uol.com.br/data folha/2020/I2/I4/ad8a599af4864554583c395d7dde7aedagp.pdf (accessed 22 December 2020).

6 José Roberto de Toledo, "Um trilhão na grelha: a nova popularidade de Bolsonaro e os 'pobres coitados", Piauí, September 2020, https://piaui. 
folha.uol.com.br/materia/um-trilhao-na-grelha/ (accessed 22 December 2020).

7 To confuse matters even more, the names of these parties had changed at regular intervals. The Progressive Party was earlier known as the Brazilian Progressive Party, the Republicanos were earlier known as the Brazilian Republican Party.

8 Agência Estado news agency, "Kassab: PSD não será 'nem esquerda, direita ou centro"”, O Estado de São Paulo, 29 March 20 I r, https:/ / politica. estadao.com.br/noticias/geral,kassab-psd-nao-sera-nem-esquerda-dire ita-ou-centro,698756 (accessed I6 January 202I).

9 Fernando de Barros E. Silva, "O Centrão e a distopia nacional", Piauí, December 2020, https://piaui.folha.uol.com.br/materia/o-centrao-edistopia-nacional/ (accessed I6 January 202I).

Io "Centrão começou a assumir vagas negociadas; presidente Jair Bolsonaro tenta se blindar com apoio do grupo", O Estado do São Paulo, 8 May 2020, https://politica.estadao.com.br/noticias/geral,relembre-as-inves tigacoes-que-envolvem-lideres-do-centrao-com-quem-bolsonaro-negocia, 70003296967 (accessed i6 January 202I).

I I Author interview with Beatriz Rey, I3 January 202I.

I2 Vinicius Valfré, "Em dois anos, Bolsonaro deixa no papel i2 grandes eixos do seu governo prometidos na campanha", O Estado de São Paulo, 2I December 2020, https://politica.estadao.com.br/noticias/geral,em-doisanos-bolsonaro-deixa-no-papel-I2-grandes-eixos-do-seu-governo-promet idos-na-campanha,7000355903I (accessed I6 January 202I).

I3 Edoardo Ghirotto, Eduardo Gonçalves and Juliana Castro, "O avanço do retrocesso", Veja, I3 January 202I, https://veja.abril.com.br/brasil/ na-pandemia-o-governo-gasta-energia-tentando-impor-agenda-conserv adora/ (accessed 2 February 202I).

I4 "Relembre as investigações que envolvem lideres do Centrão com quem bolsonaro negocia", O Estado de São Paulo, 8 May 2020, https://politica. estadao.com.br/noticias/geral,relembre-as-investigacoes-que-envolvemlideres-do-centrao-com-quem-bolsonaro-negocia,70003296967 (accessed I6 January 202I).

I5 Editorial comment, O Estado de São Paulo, 2 February 202I, https://polit ica.estadao.com.br/noticias/geral,governo-tratora-para-eleger-aliadosde-bolsonaro-no-congresso,70003602296 (accessed 3 February 202I).

I6 See https://www.bcb.gov.br/en/statistics (accessed 2 February 202I).

I7 Michael Stott, "Brazil's borrowing binge gives investors the jitters", Financial Times, 8 December 2020, https://www.ft.com/content/dfc8 ba5c-oef9-483a-ab76-4d82 Iccfoo3I (accessed I6 January 202I).

I8 José Roberto Mendonça de Barros, "Politica ambiental e entrave ao crescimento", O Estado de São Paulo, 3 January 2021, https://economia. 
estadao.com.br/noticias/geral,poitica-ambiental-e-entrave-ao-crescime nto,70003568905 (accessed i6 January 2021).

I9 See Celso Ming, "O Brasil não está quebrado. Está sem rumo", O Estado de São Paulo, 6 January 202I, https:/ / economia.estadao.com.br/noticias/ geral,o-brasil-nao-esta-quebrado-esta-sem-rumo,70003572738 (accessed I6 January 202I).

20 Celso Ming, "A desistência da Ford", O Estado de São Paulo, I3 January 202I, https://economia.estadao.com.br/noticias/geral,a-desistencia-daford, 70003580307 (accessed i6 January 202I).

2I According to a National Chamber of Commerce survey, the total number of factories fell from 384,700 to 348, IOo between 2015 and 2020. Quoted in Daniela Amorim, Mariana Durão and Márcia De Chiara, "Por dia, pelo menos I7 fábricas fecharam as portas nos últimos cinco anos", O Estado de São Paulo, I7 January 202 I, https://economia.estadao. com.br/noticias/geral,por-dia-pelo-menos-i7-fabricas-fecharam-as-por tas-nos-ultimos-cinco-anos,70003583832 (accessed 2 February 202I).

22 Poll by Instituto Travessia, Valor Econômico, 8 January 202I, https://valor. globo.com/eu-e/noticia/2021/oi /08/desemprego-e-precariedade-dasaude-serao-os-fantasmas-da-nova-decada.ghtml (accessed i6 January 202I).

23 See IMF report on commodity prices, https://www.imf.org/en/Res earch/commodity-prices27.2 (accessed 2I January 202I).

24 “'Trump é meu ídolo', diz Bolsonaro diante de comparação feita por jornalista", Istoé, I August 20I9, https://istoe.com.br/trump-e-meu-idolodiz-bolsonaro-diante-de-comparacao-feita-por-jornalista/ (accessed i6 January 202I).

25 Brian Winter, "Bolsonaro goes all in on Trump, isolation may await", Americas Quarterly, I2 January 2021, https://www.americasquarterly.org/ article/bolsonaro-goes-all-in-on-trump-isolation-may-await/ (accessed i6 January 202I).

26 Oliver Stuenkel, "Política antiglobalista de Bolsonaro tem um preço", O Estado de São Paulo, 3 January 202 I, https://economia.estadao.com. $\mathrm{br} /$ noticias/geral,politica-antiglobalista-de-bolsonaro-tem-um-preco,70 003568982 (accessed i6 January 202I).

27 Mendonça de Barros, "Politica ambiental e entrave ao crescimento".

28 Larissa Wachholz and Lígia Dutra, "A agenda ambiental da China e a agropecuária brasileira”, Valor Econômico, I8 January 202 I, https://valor. globo.com/opiniao/coluna/a-agenda-ambiental-da-china-e-a-agropec uaria-brasileira.ghtml (accessed 2 February 202I).

29 Stuenkel, "Política antiglobalista de Bolsonaro tem um preço".

30 Anthony Boadle, "New Brazil coronavirus variant found in nearly half of Amazon city cases", Reuters, 22 January 202I, https://www.reuters.com/ article/instant-article/idUSLIN2JXI2T (accessed 2 February 202I). 
3I See Joel Zinberg, "Trump isn't the one politicizing science”, Wall Street Journal, I4 December 2020, https://www.wsj.com/articles/trump-isntthe-one-politicizing-science-I 607969209 (accessed I6 January 202 I).

32 See Michael S. Saag, "Misguided use of hydroxychloroquine for COVIDI9: the infusion of politics into science", FAMA fournal of the American Medical Association (JAMA Network), 9 November 2020, https://jamanet work.com/journals/jama/fullarticle/277292 I (accessed I6 January 202I).

33 See Mandetta, Um paciente chamado Brasil, I44-5.

34 Gabriel Stargardter and Lisandra Paraguassu, "Bolsonaro bets 'miraculous cure' for Covid ig can save Brazil and his life", Reuters, 8 July 2020, https://www.reuters.com/article/us-health-coronavirus-brazil-hydrox ychlo-idUSKBN249396 (accessed I6 January 202I); Estella Ektorp, "Death threats after a trial on chloroquine for Covid i9", The Lancet, June 2020, https://www.thelancet.com/journals/laninf/article/PIISI473-30 99(20)30383-2/fulltext (accessed I6 January 202I); Claudio Angelo, "Contra a besta-fera: a luta dos cientistas brasileiros para combater o vírus é dura - vai de propaganda enganosa a ameaça de mort", Piauí, July 2020, https://piaui.folha.uol.com.br/materia/contra-besta-fera/ (accessed 2 April 202I).

35 Paulo Sampaio, "Para médica Nise Yamaguchi, comunidade científica conspira contra a vida", UOL, I9 July 2020, https://noticias.uol.com. br/colunas/paulo-sampaio/2020/o7/ig/para-medica-nise-yamaguchicomunidade-cientifica-conspira-contra-a-vida.htm (accessed I6 January 202I).

36 Ibid.

37 Ibid.

$3^{8}$ Simone Preissler Iglesias and Samy Adghirni, "Brazil's evangelicals take over while Bolsonaro's allies jump ship", Bloomberg, 5 June 2020, https:// www.bloomberg.com/news/articles/2020-06-05/evangelicals-take-overwhile-bolsonaro-s-allies-jump-ship (accessed I6 January 202I).

39 Edoardo Ghirotto, Gabriel Mascarenhas, Laryssa Borges and Nonato Viegas, "Ele está entre nós", Veja, 27January 2021, https://veja.abril.com. br/politica/inicio-da-vacinacao-muda-jogo-politico-e-aumenta-pressaosobre-bolsonaro/ (accessed 2 February 202I).

40 Ibid.

4 I Ibid.

42 https://interactives.lowyinstitute.org/features/covid-performance/\#ran kings (accessed 22 March 202I).

43 "Na íntegra: o que diz a dura carta de banqueiros e economistas com críticas a Bolsonaro e propostas para pandemia", BBC News Brazil, 22 March 202I, https://www.bbc.com/portuguese/brasil-56485687 (accessed 2 April 202I). 


\section{NOTES}

44 André Shalders, "Lira dá 'sinal amarelo' ao governo por erros na pandemia e diz que 'remédio legislativo' pode ser 'fatal", O Estado de São Paulo, 24 March 2021, https://politica.estadao.com.br/blogs/fausto-mac edo/lira-da-sinal-amarelo-ao-governo-por-erros-na-pandemia-e-diz-que -remedio-legislativo-pode-ser-fatal/ (accessed 2 April 202I).

45 Fausto Pinato, deputy for the Progressive Party, quoted in Felipe Frazão and André Shalders, "Centrão e mercado dão ultimato a Bolsonaro", O Estado de São Paulo, 28 March 202 I, https:/ / politica.estadao.com.br/noti cias/geral,centrao-e-mercado-dao-ultimato-a-bolsonaro,700036628I9 (accessed 2 April 202I). 